Dag Solhjell, kunstsosiolog og dr. philos

Adresse: Syd-Fossum 55,

1359 Eiksmarka

Norge

E-mail:dsolhjel@online.no
Amy K. Levin (red.): Gender, sexuality, and New York, Routledge. 2010. 322 sider. ISBN 978-0415-55492-3.

Dette er en tankevækkende, men problematisk artikelsamling. Der er rigtigt gode indlæg imellem, men bogen ville vinde ved en mere målrettet redaktion. Antologien er redigeret af Amy Levin fra Northern Illinois University, hvis særinteresse er naturvidenskabelige museer, men de 25 indlæg dækker en bred vifte af historiske, arkæologiske, naturvidenskabelige og kunsthistoriske, lokale og nationale museer - og det amerikanske kreationistmuseum! Indlæggene er ordnet tematisk i fire dele: "Women in museum work", "Theories", "Collections and exhibitions", "Case studies". De fleste indlæg er skrevet inden for de sidste ti år, flere specifikt til denne antologi. Det geografiske fokus er uforklarligt snævert: 20 af de 25 kapitler fokuserer på Storbritannien og USA, med yderligere et hver om museer i Canada, Australien, og Israel, og ét om Marokko, Kuwait og Jordan. Det sidste kapitel er en biografisk oversigt, igen rent engelsksproget og angloamerikansk orienteret. Trods flere sidebemærkninger om tyske udstillinger og museer undervejs, er der ingen indlæg om Tyskland, og fraværet af den norske udstilling Imod naturen er nærmest uforklarligt (se fx Alaimo 2010: 51ff).

Det regionale perspektiv begrænser antologiens anvendelighed. Det er tydeligt, at Storbritannien og USA ikke er forgangslande på ligestillingsområdet. Især kapitlerne om seksualitet præges af forvirrende og forældede diskussioner af section 28, en britisk lov, der forhindrede offentlig finansiering af undervisning, udstillinger og andre tiltag, der kunne 
"fremme homoseksualitet". Den blev vedtaget i 1988, og afskaffet i 2003. Loven var almindeligt frygtet i den britiske museumsverden, men meget ujævnt håndhævet.

Antologien definerer sine emner snævert. Redaktøren fremhæver, at "gender" her alene handler om kvinder. Der er ingen diskussioner af maskulinitet i antologien. Tilsvarende er "sexuality" næsten begrænset til homoseksualitet. Kun én artikel, af Erica Rand fra Bates College, diskuterer heteroseksualiteter som vidensobjekt.

Hver del af bogen begynder med en meget kort introduktion, hvor redaktøren blandt andet opsummerer museumshistorie på 21/2 side, feminisme i ét tekstafsnit, og queerteori på én side. Jeg savner en mere udførlig diskussion, også fordi de forskellige indlæg ikke er helt kompatible med hinanden.

\section{DE SFEDVANLIGE, SURE OPSTØD}

Indlæggene varierer meget i teoretisk og metodisk tilgang. En del viser en "offerfeminisme" eller "kvotefeminisme", der virker lidt forældet $\mathrm{i}$ dag. Det gælder $\mathrm{fx}$ for den tidligere leder af Chicagos børnemuseum, Marjorie Schwartzers diskussion af amerikanske museers ledelse: der er flere kvinder end mænd i lavtlønnede museumsstillinger, flere mænd end kvinder i ledelsen, og uerfarne mænd bliver ansat som ledere frem for erfarne kvinder. Formuleringen antyder, at Schwartzer ville foretrække uerfarne kvindelige chefer. Hun synes heller ikke, at opfatte museernes manglende evne til at rekruttere mænd, som et problem. Her handler ligestilling kun om, at give kvinder bedre vilkår.

Tilsvarende bemærker Ruth Adams fra King's College, London spydigt, at "men might be unwilling to work their way up" i Storbritanniens museumsverden. Hun beskriver imidlertid et system, hvor ledere (uanset køn) rekrutteres udefra. Her synes hverken mænd eller kvinder i stand til at arbejde sig op, uanset vilje. Adams' indlæg fokuserer på Elizabeth EsteveColl, direktør for The Victoria and Albert Museum fra 1987-1995. Adams mener, at EsteveColl var upopulær, fordi hun var en kvindelig leder. Som leder var hun ansvarlig for store besparelser, og for en ændring af udstillingspolitikken, med det mål at gøre V\&A mere attraktivt for et købedygtigt (yuppie) publikum. Alligevel vælger Adams ikke at bedømme den kvindelige leder på hendes bedrifter, men alene på køn. Det er en slags omvendt sexisme, en sørgeligt klassisk offerteori.

Redaktørens Levins egen diskussion af tre museer viser en nyere, men ligeså problematisk, teoretisk tilgang. Både på den (siden ombyggede) naturvidenskabelige afdeling af Skotlands Nationalmuseum, på Londons teknologimuseum og på kreationistmuseet i Cincinnati, Ohio ser Levin samme problem: museerne naturaliserer heteroseksualitet og mandlig autoritet. Levin mener, at mandlige tegn (hvalpenis i Edinburgh) er forkerte, stærke kvinder (Medusa i London, hindugudinder i Edinburgh) er forkerte, og svage kvinder (Eva i Cincinnati) er forkerte. Religion er forkert, videnskabelig autoritet er forkert, og lumre vittigheder, der undergraver denne autoritet, er forkerte. Kritikken er rent negativ, og dermed ret uproduktiv. Levins kritik er nok berettiget, men den given ingen vejledning $i$, hvordan vi kan forbedre museerne. Det er også bemærkelsesværdigt, at Levin alene forholder sig til museet som formidling, og helt undgår diskussioner af udstillingernes videnskabelige værdi.

\section{... OG NOGET NYT}

Der er heldigvis langt mere teoretisk kød på 
resten af bogen. Rebecca Manching fra Manchester Naturhistoriske Museum giver en strålende diskussion af udstoppede dyr dér. Også hun er optaget af kvoter, men hun er overbevisende i sin argumentation for, hvorfor de er vigtige. Manching ser museet som en præskriptiv tekst, der præsenterer en idealfortælling om det naturlige. Hun argumenterer overbevisende for, hvorfor det er vigtigt, at udstille hundyr, og hvorfor de ikke uden god grund bør fremstilles som passive og svage. Desuden giver hun fine eksempler på, hvordan man kan problematisere en udstilling med enkle midler, også uden store budgetter, nye præparater eller omfattende ombygninger. Her er en klar, anvendelig opskrift på bedre udstillinger og på, hvordan den enkelte kurator kan gøre en forskel.

Tamar Katriel fra Haifa universitet, Israel, bidrager med et indlæg om israelske kibbutzmuseer, som også er solidt forankret i den klassiske feminisme, men er lige så klart som Manchings om, hvorfor kritikken er vigtig: kibbutzerne byggede på en ideologi om ligestilling. I virkeligheden levede beboerne ikke altid op til idealerne. Alligevel giver de museer, Katriel beskriver, publikum et rosenrødt billede af kibbutzlivet samtidigt med, at de fremstiller sexisme som en naturlig og acceptabel del af dette ideal. Hun dokumenterer også, hvordan samme museumsrum kan udnyttes forskelligt: myten om de ligestillede kibbutzer bliver både gengivet ukritisk, brugt til at problematisere nutidens kønsroller i Israel ("Dengang gad pigerne arbejde for ligestilling”), og afsløret som en ideologisk konstruktion.

De to mest teoretiske sofistikerede genderindlæg er måske Hilda Heins (kvindestudier, Brandeis University, USA) og Barbara Clark Smiths (American Museum of Natural Histo- ry, USA). Hein argumenterer, sammenhængende, men kontroversielt, for en feministisk kritik af den vestlige epistemologi. Hun lægger vægt på, at "'Wov!' is as good as "why?'”, og på, at museer ikke kun skal give tør viden, men også oplevelser. Det er en pointe, der harmonerer meget fint med flere indlæg om seksualitet. Smith påpeger, at vi ikke kan gå ud fra, at vi allerede ved, hvad publikum vil have, og at vi ikke kan gå ud fra, at markedsanalyser, oprindeligt designet til reklameindustrien, kan belyse dette. De kan måske fortælle os, hvad publikum vil købe, men ikke altid, hvad de kan lære. Hun plæderer overbevisende for, at kønsperspektiver kan bruges overalt. Som eksempel nævner hun flyvtekniske museer, der ikke behøver at lede efter kvindelige piloter for at udvikle en mere feministisk tilgang til udstillingerne: det er lige så interessant at tydeliggøre, hvordan og hvorfor flyteknologien blev til i et næsten rent mandligt miljø.

\section{USYNLIGHED}

Andre indlæg fokuserer på usynlighed. Dette er måske det eneste emne, der forbinder antologiens to temaer, køn og seksualitet. Især to indlæg fortjener omtale: Laura Brandon fra Canadas krigsmuseums skriver om museets samling af malerier, oftest lavet af militærets udsendte kunstnere. De fleste af disse viser mandlige soldater i krig. Brandon fremhæver, at også kvindernes liv på hjemmefronten ændredes af krigene. Hun giver nogle få eksempler på relevante kunstværker, ofte malet af kvinder, men det er tydeligt, at museet reelt mangler relevant materiale. Hendes indsats for at inkludere kvinder i museet har derfor resulteret i en ny data- og materialeindsamling.

Den vigtigste og bedste tekst om usynlighed er imidlertid Anna Conlans (kurator ved 
160 James Galleries, University of New York) diskussion af et foto af Alice B. Toklas. Toklas dannede par med Getrude Stein i Paris, indtil Steins død. Derefter blev Picassos portræt af Stein overdraget til The Metropolitan Museum i New York. Det relevante foto viser den første genforening af Toklas og portrættet. Conlans tekst fokuserer på sorg og længsel, og museets rolle som minde og monument. Det er en af de få tekster i bogen, der for alvor diskuterer, hvorfor museer er vigtige, og for hvem.

\section{SEKSuALitet}

Indlæggene om seksualitet er lige så ujævne i tilgangen som indlæggene om køn. Robert Mills' (King's College, London) "Queer is here" er en klassiker, og fortjener at blive læst af flere. Kort opsummeret er hans pointe, at en queer-udstilling altid må være ironisk og problematisk. Den må altid undgå kanonisering. Mills skriver sig op imod en kronik af den britiske aktivist Peter Thatchell, og det er lidt overraskende, at denne ikke er genoptrykt i antologien.

Paul Gabriels, der har arbejdet for forskellige universiteter i USA og Taiwan, skriver charmerende og selvironisk om sine egne oplevelser som kurator ved San Franciscos GLBTHS (Gay Lesbian Bisexual and Transsexual History Society), men hans idé om "erotisk intelligens" synes søgt. Teksten fortjener, at blive læst for Gabriels erfaringer, og for sin vægt på, at minoritetskulturer ikke kun handler om sex. Den fortjener også kritik.

Erica Rands fra kvindestudier, Bates College, Maine, leverer med sin analyse af sex på Ellis Island en af de mest teoretisk sofistikerede tekster $\mathrm{i}$ antologien, og den eneste, der virkeligt synliggør, at seksualiteter i flertal er relevante overalt. Rand skriver om prostitution, ægteskab, udenomsaffærer, pornografi og en række andre aspekter af seksualiteten, der er helt centrale og helt usynlige i forståelsen af den amerikanske immigrationshistorie.

Blandt de mere praktiske tekster er der en markant kontrast mellem to indlæg: Michael Petry (kunstner og kurator, London) giver en skræmmende beskrivelse af sine oplevelser som kurator for en kunstudstilling i England. Han forsøgte, at samle kunstværker lavet af feterede mandlige kunstnere med reference til deres mandlige elskere. De fleste af disse værker var allerede udstillet andetsteds. Det nye i udstillingen var, at værkernes eksplicit blev sat i forbindelse med kunstnernes seksualitet. Dette førte til uunderbyggede rygter om, at udstillingen bestod af (børne-) porno, og førte til en panik hvor det lokale kommunalråd censurerede udstillingen på en meget lidt professionel måde. Derimod beskriver Angela Vanegas (tidligere Croydon Museums, London) en yderst succesfuld indsats for at gøre homoseksualitet mere synligt på et lokalmuseum i Londonforstaden Croydon. Hun diskuterer hvorfor, hvordan og hvilke problemer, der opstod, og viser overbevisende, at den færdige udstilling ikke reproducerede stereotyper, men tillod de interviewede selv at sætte grænser og dagsordener. Det virker som et eksempel til efterfølgelse.

\section{GENNEMGÅENDE TEMAER}

Et af de gennemgående emner er som sagt censur og inklusion: Vanegas argumenterer for, at museer har en pligt til, at repræsentere hele befolkningen, også minoriteter. Smith argumenterer for, at ingen udstilling er lige interessant for alle besøgende. Petry og Vanegas beskriver begge nyere angreb på udstillinger, der søgte at inkludere seksuelle minoriteter, 
og Frost beskriver den historiske tradition for at skjule dele af museets samling i "hemmelige museer". Modsat viser Gavin Butt (Visual studies, Goldsmith's college, London), hvordan museer kan være aktive agenter i at blåstemple kontroversielle kunstværker, og også Stuart Frost (Victoria \& Albert, London) spekulerer over, hvordan det romerske Warrenbægers alder og association med British Museum gør det mere acceptabelt end moderne fremstillinger af sammenlignelige pornografiske motiver. Gabriels beskriver interne debatter i GLBTHS, hvor nogle udstillinger blev beskyldt for et for ensidigt fokus på mænd (for meget G, og for lidt LBT), og hvor gruppen i ét tilfælde valgte at fjerne et tidsskrift lavet af homoseksuelle, racistiske skateboardere ("gay nazis"). Et helt oplagt spørgsmål, som desværre kun behandles perifert, er spørgsmålet om, hvem der har ret til censur, og på hvilket grundlag. Vanegas plæderer for homoseksuelles (og andres) ret til selv at kontrollere, hvordan de fremstilles i udstillinger, og for alles ret til repræsentation, mens Gabriels synes at nægte racister samme ret til selvudtryk. Vanegas understreger, at offentlige museer har en særlig pligt til at sikre, at alle er repræsenterede. Det er en debat, jeg gerne så udviklet mere. Bør vi udøve selvcensur, og på hvilket grundlag? Hvem har autoritet her?

Et andet spørgsmål gælder museernes selvopfattelse: er en museumsudstilling en blåstempling af det udstillede? Levin understreger flere gange, at museerne skal undgå stereotyper, og fx ikke kun fokusere på homoseksuelle som ofre (for AIDS, for vold, for Nazisternes udryddelseslejre). Modsat ser Conlan sorg som helt centralt i sin diskussion af Alice B. Toklas på museet. Indvandringsmuseet på Ellis Island fejrer indvandring som en god ting, og er som beskrevet af Rand for ukritisk i sin fortælling om USA's åbenhed på området. Kreationistmuseet i Cincinnati fejrer biblen og kristendommen, og Gail Levins (kunsthistorie, Baruch college, New York) kritik af Whitney-galleriets usynliggørelse af Jo Hopper går på, at de ikke fejrer hende på lige fod med hendes mand. Er det alene museets rolle at fejre det udstillede, som mesterværker, som dokumentation af kulturel og naturlig diversitet, som levende kulturel tradition, eller rummer museet også plads til dokumentation af konflikter, vrede og sorg (jf. Conlan)? Kan museer udstille værker, kulturer eller begivenheder, uden at blåstemple disse? Er museet altid en reaktionær institution, der alene kan fejre det samfund, vi har nu, eventuelt i kontrast til tidligere tiders diskrimination? Jeg mistænker, at forskellige typer museum her må acceptere forskellige ansvarsdefinitioner, men jeg savner en diskussion.

Et tredje gennemgående tema er kontekstualisering. Vanegas giver et eksempel på en lesbisk kvinde, der fortalte om sine genvordigheder med at blive uddannet som elektriker i 1960erne, og som lånte museet en af sine skruetrækkere til udstilling. Der er en logisk sammenhæng mellem køn, seksualitet og problemerne med at blive accepteret som kvinde i et traditionelt mandefag, men en lesbisk elektrikers skruetrækker er ikke genkendelig som sådan uden baggrundsinformation. Brandon fremhæver en kvinde, hvis historie blev del af Canadas krigsarkiv, da hendes tidligere kærestes mor testamenterede sønnens mindeportræt og medaljer til hende, som den sidste der kunne huske sønnen. Modsat fremhæver hun også, at det var næsten umuligt at finde de få krigsbilleder, der faktisk viser kvinder, fordi registreringen ikke nævnte dette, og Petry fremhæver, hvordan museer har skjult kunstneres (velkendte) seksualitet med tvetydige og 
162 misvisende forklaringer, og hvordan ærlighed på dette punkt kan udløse censur udefra. Det overordnede budskab synes, at være, at der er brug for så megen "tyk" beskrivelse som muligt. Hvis museumssamlinger skal have nogen anvendelse for senere generationer af kuratorer, er det vigtigt, at alle tilgængelige informationer er registeret.

\section{TO BØGER I EN INDBINDING: ET FORNUFT-} SÆGTESKAB?

Der er en ret klar opdeling i antologien, hvor nogle indlæg handler om kvinder ("gender"), andre om (homo-)seksualitet. Der er påfaldende lidt kommunikation mellem de to dele. Det er særligt slående, når fx Robert Ridinger (University of Northern Illinois og the Leather Archives \& Museum, USA) bemærker, at græsrodsarkiver for homoseksuel kultur ofte har fokuseret på politisk aktivisme. Modsvarende er der intet $\mathrm{i}$ "gender"-indlæggene om politik: hvis kvindesagen er dokumenteret, er det ikke noget feministerne diskuterer. Denne udeladelse overrasker mig: der findes faktisk relevante museer, fx Kvindemuseet i Århus, Danmark (se også Schofield \& Anderton 2000: 237ff).

Denne mangel på dialog kan rejse tvivl om, om det overhovedet giver mening at kombinere køn og seksualitet i én antologi. Der er forskere og kritikere, der kombinerer begge tilgange (her tydeligst Rand), men der er også mange homo- og queeraktivister, der er sørgeligt uvidende om feministisk teori, og mange feminister, der er lige så uvidende om queerteori. Antologien viser, at disse forskellige grupper ganske ofte arbejder parallelt, og den kan måske opfordre til større samarbejde. Alligevel virker "Gender, sexuality, and museums" som to bøger i én indbinding.
En sidste bemærkning: layoutet er ikke brugervenligt. Forlaget har valgt en meget lille skrifttype, og teksterne står tæt. Først på side 206 afsløres det, hvor forsidebilledet stammer fra. Bogen ville vinde meget ved lidt mere introduktion, og ved mere diskussion om, hvordan indlæggene passer sammen eller støder sammen. Forlaget fremhæver, at det er 15 år siden, vi sidst så en gender-antologi, og at ingen har samlet museologiske LGB-indlæg før. Dette er nok den bedste antologi, vi kommer til at se på området længe. Desværre.

\section{LITTERATUR}

Alaimo, Stacy: "Escaping capture: the pleasure of queer animals" i Mortimer-Sandilands, Catriona \& Erickson, Bruce (red.): Queer ecologies: sex, nature, politic, desire, Indiana University Press: Bloomington \& Indianapolis. 2010.

Schofield, John \& Anderton, Mike 2000: "The queer archaeology of Green Gate: interpreting contested space at Greenham Common Airbase". World Archaeology 32(2) 236-251.

Bo Jensen, Arkaolog, ph.d.

Adresse: Stenhuggervej 6, 4. Th

2400 København, Danmark

Email: Bojensen_dk@yahoo.dk 